\title{
Some Reliefs Representing the King in the Heb Sed Robe Discovered in the Henket-Ankh
}

\author{
LINDA CHAPON
}

\begin{abstract}
During the archaeological fieldwork undertaken in the Henket-Ankh, the Temple of Millions of Years of Thutmose III situated between el-Assasif and el-Khokha, a large amount of sandstone blocks and fragments have been discovered. Although they are quite fragmented, they enable us to posit a hypothesis about some of the scenes that were originally carved on the temple's walls. This paper focuses mainly on the fragments representing the king in the Heb Sed robe. The Heb Sed robe embodies royal power regeneration. It is therefore especially significant in the Temples of Millions of Years where this aspect played a key role. These reliefs would contribute to the already known iconographic corpus of this period, as well as to the understanding of the temple iconographic programme and function.
\end{abstract}

Keywords: New Kingdom Egypt, Heb Sed, Thutmose III, iconography, royal rite, Iunmutef, Heneket-Ankh

Linda Chapon, University of Granada, Granada / Institute of Egyptology of Tübingen, Tübingen; lindachapon2002@hotmail.com

The archaeological fieldwork undertaken in the Henket-Ankh, the Temple of Millions of Years of Thutmose III, ${ }^{1}$ have brought to light a large amount of materials. Mainly unpublished, ${ }^{2}$ thousands of fragments belonging to sandstone reliefs of the fallen temple

\footnotetext{
1 The place chosen for the construction of the temple was situated between el-Assasif and el-Khokha, on the boundary between the arable land and the desert. For a synthesis of the fieldworks carried out at the site and a description of the temple, see: Seco Álvarez, Radwan 2010; Seco Álvarez et al. 2012-2013; Seco Álvarez 2014; 2015. Works at the temple were for the first time conducted in 1888-1889 by George E.J. Daressy (Daressy 1926: 13-14), renewed at the beginning of the twentieth century by Arthur E.P.B. Weigall (Weigall 1906: 121-141), and then continued by Herbert Ricke (Ricke 1939) during seasons 1934-1938. In 2008 began the Spanish-Egyptian Project directed by the Myriam Seco Álvarez. This is a joint project of the Ministry of Antiquities and the Academy of Fine Arts of Seville, collaborating with the University of Granada (Spain) and the Institute of Egyptology of Tübingen (Germany).

${ }^{2}$ Only a few blocks or their fragments were already published by Ricke (Ricke 1939). Others blocks were published by members of the project (e.g. Martínez Babón 2015) as well as by the present author as part of her $\mathrm{PhD}$ thesis (Chapon 2016).
} 
walls have been discovered. This paper aims to present some fragments representing the king in the Heb Sed robe. Scenes including this kind of garment seem to have been especially important in the iconographic program of Temples of Millions of Years. ${ }^{3}$

Indubitably, when facing the study of a material that is quite fragmented, reliefs showing the king in the Heb Sed robe are easy to identify. Before the reign of Amenhotep III, ${ }^{4}$ the typical white Heb Sed robe is short, covering the arms and upper body down to the thighs but leaving free hands and insignia. Contrary to the Egyptian convention, the king is frequently represented with the torso in profile. ${ }^{5}$ The front of the robe is vertical. However, in the case of enthroned figures the robe is extended down the thighs. The legs are usually mummiform, so that one of them is hidden. The most usual insignia associated with the king's figure are the Upper or Lower Egyptian Crown, the Double Crown, the $n h 3$ h 3 -flail and the $h k 3$-scepter. The sceptre may take sometimes the form of the ${ }^{~}{ }^{w} t$-stick. ${ }^{6}$ The $\mathrm{Heb}$ Sed robe embodies royal power regeneration, ${ }^{7}$ particularly in the course of the Heb Sed ceremony, which aims to sanction the eternal renewal of the king's authority and cult on earth and underworld. ${ }^{8}$ All evidence seems to indicate that the moment when the king was outfitted with the Heb Sed robe symbolises the key episode of the ritual. ${ }^{9}$ However, the Heb Sed ritual was composed of several other episodes during which the king wore different garments. ${ }^{10}$ Nonetheless, the present state of the material discovered in the temple makes it difficult to identify these episodes.

Eventually, we should take into account that this kind of clothing, directly associated with the renewal of the royal office, could be by assimilation used in ritual contexts connected with the royal sphere that may have nothing to do directly with the Heb Sed ceremony. ${ }^{11}$ This seems to be the case in several scenes showing Thutmose III in the Heb Sed robe dated to the coregency, where the young king was included in the iconographic and propagandistic programme established by Hatshepsut for clear political reasons. ${ }^{12}$ Seven scenes show royal figures in the Heb Sed robe in the Temple of Hatshepsut at Deir

${ }^{3}$ Bonhême, Forgeau 1988: 296-297; Leblanc 2010: 46-53; Ullmann 2002: 661-670; Rummel 2010: 162; Hornung, Staehelin 1974: 85.

${ }^{4}$ Scenes where the king wears the Heb Sed robe are known since the beginning of dynastic times to the Ptolemaic period. For a listing of evidence connected to the Heb Sed festival see: Hornung, Staehelin 2006: 13-32.

${ }^{5}$ On some representations of the king in the Heb Sed robe torso and arms are shown frontally. This is the case of the scenes found in the Sokarian room SK6 of the Akh-menu. No representations of this kind have been identified among the material discovered in the Henket-Ankh.

${ }^{6}$ See: Bonhême, Forgeau 1988: 294-306; Hornung, Staehelin 1974: 49-50.

7 The robe was made of $j d m j$-linen. This material is connected with the regenerative properties of mummy bindings. Furthermore, it is identified in inscriptions as a medium through which renewal was performed, especially in the context of the Heb Sed (Rummel 2006: 398-401).

${ }^{8}$ Bonhême, Forgeau 1988: 287-289; Hornung, Staehelin 2006: 41-46, 97; Bleeker 1967: 113-123.

${ }^{9}$ Rummel 2006: 392-395.

${ }_{10}$ This include: the usual official ceremonial kilt, the shroud associated with the symbolical death of the king, the typical Heb Sed robe, the Shendyt used for the royal race and finally once again the kilt (Bonhême, Forgeau 1988: 296; Bleeker 1967: 120-121).

11 Karkowski 2001: 109-112; Rummel 2006: 402-404.

${ }^{12}$ See, for example: Davies 2004; Sankiewicz 2010. For the idea of a Heb Sed ceremony celebrated by Hatshepsut and Thutmose III at the same time, see: Uphill 1961. 
el-Bahari, from which four comprise both rulers placed side by side. ${ }^{13}$ In the first one, the queen and Thutmose III are sitting inside a pavilion by a Fishing and Fowling scene on the northern wing of the Lower Portico. The other three, located on the eastern wall of the Upper Court, depict the sovereigns on board the royal barque during river processions. ${ }^{14}$ An analogous scene is preserved in the Chapelle Rouge at Karnak. ${ }^{15}$ At Deir el-Bahari, they seem to be once more represented in a double Heb Sed pavilion situated above the doorway of Hatshepsut's Offering Hall. ${ }^{16}$ It is a fact that none of these representations appear to be connected neither to a real celebration of the Heb Sed nor to the episodes that could have been involved in this ceremony. ${ }^{17}$

The reliefs from Akh-menu complex at Karnak, constructed by Thutmose III just after the death of Hatshepsut, display several episodes that may be connected to the Heb Sed symbolic ceremony. A first group of scenes is found on the northern wall of the southern magazines' corridor that runs west to east. In the first part of the corridor, the king was probably shown sitting on a throne followed by Iunmutef and facing the Great Ennead. Following this scene, two registers show the king leaving the palace, performing several ritual races, and finally sitting, dressed in the Heb Sed robe, inside a pavilion in the lower register. ${ }^{18}$ In the second part of the corridor, the king follows Iunmutef heading towards a scene of the shooting of the arrows in the upper register, while he was standing in the $\mathrm{Heb} \mathrm{Sed}$ robe in the lower one. ${ }^{19}$ Another set of scenes shows precious offerings presented to the king sitting in the Heb Sed robe inside a pavilion; Thutmose III is also standing behind the pavilion. ${ }^{20}$

The Heb Sed theme continues in the so-called Sokarian rooms of the Akh-menu where the king is twice seen with a characteristic robe, but this time with crossed arms, in the lower register of the northern wall of the room SK6, while he is sitting inside a pavilion facing the ritual race on the eastern wall of SK5. ${ }^{21}$ In the temple of Dakka, a block preserves the figures of Thutmose III sitting on a throne and performing the ritual race. ${ }^{22}$ Finally, some scenes show the divinised Sesostris III in the Heb Sed robe at the temple

${ }^{13}$ Hatshepsut is represented alone in three scenes of the northern wing of the Middle Portico. Thutmose III was not depicted there most probably because it was the area where the divine birth cycle and the proclamation of the queen as successor were fulfilled (Karkowski 2001: Figs 4-6). Thutmose I is represented twice posthumously (Naville 1898: P1. LX, 6; Karkowski 2001: Figs 5, 10, 11).

14 Karkowski 2001: Figs 1, 7-9, respectively.

15 Lacau, Chevrier 1977-1979: 182-183, P1. 9, block 171; Burgos, Larché 2006: 61; PM II², 113; Barguet 1962: 163-165; Hornung, Staehelin 2006: 51-52.

16 Karkowski 2001: Fig. 12.

17 Karkowski 2001: 109-112; Hornung, Staehelin 2006: 51-56.

18 PM II², 113; Barguet 1962: 163-165; Hornung, Staehelin 2006: 60.

19 LD III, Pl. 36b; PM II², 113; Barguet 1962: 165-166; Hornung, Staehelin 2006: 60; Rummel 2010: 160-161, cat. no. 15. Through this ritual, the king in the presence of Thoth reclaims possession of the dominions under his rule.

${ }^{20}$ LD III, P1. 36a; PM II², 113; Barguet 1962: 165-166.

${ }^{21}$ Masquelier-Loorius 2017. See also: PM II², 116 (373); Barguet 1962: 187-190. I would like to thank Julie Masquelier-Loorius for kind consultations.

22 Farid 1979: 5, Fig. 1. 
of Semna. ${ }^{23}$ In this case, it is not a reigning king, neither direct predecessor - as happens with Thutmose I in Hatshepsut's temple at Deir el-Bahari - but a Middle Kingdom ancestor receiving a specific cult in the temple of Semna that wears the Heb Sed robe.

A reference to statuary should also be made as the statuary and relief programmes of the temples were closely interrelated. Several statues representing the king in the Heb Sed robe are dated to Thutmose III's reign. ${ }^{24}$ It is especially interesting to mention a headless diorite statue (Cairo JE 38335) found in the Henket-Ankh representing the king in a long cloak. ${ }^{25}$

\section{THE RELIEFS}

So far, seven sandstone fragments in bas-relief preserving part of a figure in the Heb Sed robe have been identified among the material from the Temple of Millions of Years of Thutmose III. Other two fragments connected to this motif depict Iunmutef. One of them includes also part of a dais on which most probably a pavilion with a king in the Heb Sed robe was originally represented. All these reliefs were mainly found without context in the so-called Weigall-Ricke magazine. This was constructed by Arthur E.P.B. Weigall on the western side of the temple, and it was later rebuilt by Herbert Ricke in the thirties of the twentieth century. ${ }^{26}$

\section{THE KING SITTING ON A THRONE INSIDE THE DOUBLE PAVILION}

Four very well preserved fragments have been identified as belonging to the same scene. The identification was possible thanks to the size of fragments and their polychrome and iconographic elements. The first one, inv. no. 930 (Fig. 1a), shows the upper part of the king in the Heb Sed robe oriented towards the left. The king wears the White Crown, a blue beard, a blue-green-blue-yellow necklace with yellow counterpoise divided in five red and blue rectangles, and a golden bracelet on the right hand. With this same hand, he holds two insignia, the $n h 3 h$ 3-flail and a sceptre. ${ }^{27}$ At his back, two signs are well-preserved, ' $n h$ ' and ' $R^{\odot}$, which are part of the formula ' $d j$ ' $n h$ mj $R^{\odot}$, ' given life, like Re'.

The second fragment, inv. no. 1049 (Fig. 1b), most probably corresponds to the lowermost part of the back of the same figure sitting on a throne. Behind his back, just above the backrest of the throne, there is a sign ' $m j$ ', which undoubtedly pertained to the continuation of the formula identified on the previous fragment. To the right, two vertical yellow elements could belong to poles of a double Heb Sed pavilion.

\footnotetext{
${ }^{23}$ Caminos 1998: Pls 50-60; Hornung, Staehelin 2006: 56-57.

${ }^{24}$ For an inventory of sculptures, see: Sourouzian 1994: 499-530.

25 Sourouzian 1994: 518, no. 29; Laboury 1998: 254-255, C 86; Hornung, Staehelin 2006: 23.

26 Seco Álvarez et al. 2010. When the Spanish-Egyptian mission opened the magazine in 2008, it contained a great amount of sandstone and limestone fragmented reliefs discovered by our predecessors.

${ }^{27}$ It is likely the ' $w t$-stick since the lower part of the same insignia, preserved on fragment inv. no. 893, does not correspond to the $h k 3$-scepter. The $h k 3$-scepter is represented at the Akh-menu but at Deir el-Bahari the ' $w t$-stick is mainly attested.
} 


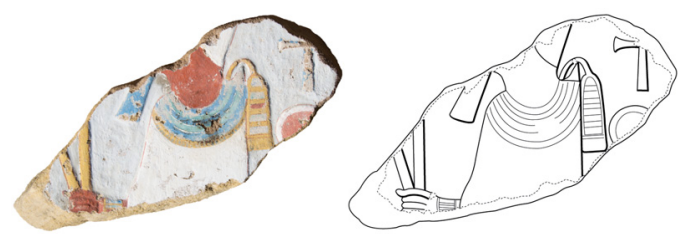

a
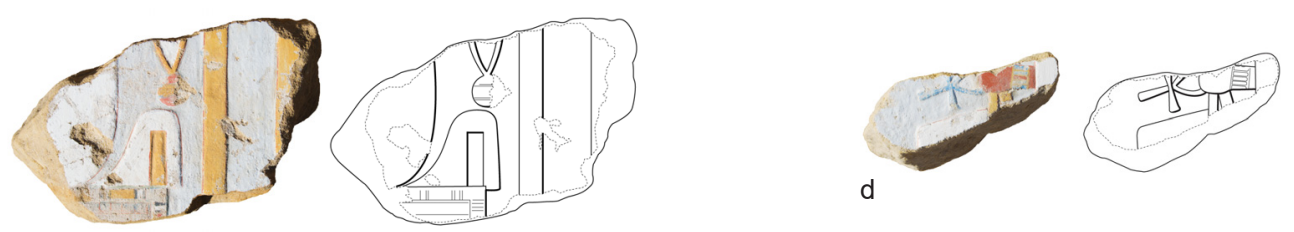

b
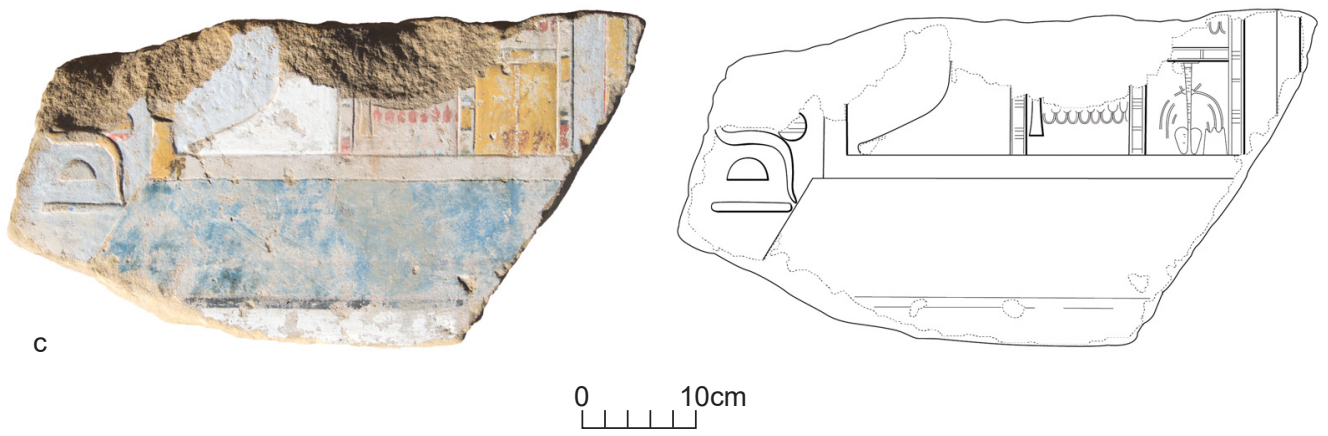

1. Enthroned figure in the Heb Sed robe: a. upper part of the figure, block inv. no. 930; b. back part of the figure, block inv. no. 1049; c. lower part of the figure, block inv. no. 893; d. part of the figure's left hand holding a sign ' $n h$, block inv. no. 14841 (Phot. and drawing: L. Chapon (C) Thutmosis III Temple Project).

The third fragment, inv. no. 893 (Fig. 1c), shows the lower part of the throne and mummiform feet. Poles delimiting a pavilion are visible on both left and right sides, and the pavilion stands on a dais with blue colour and black baseline. Under the baseline, the beginning of an area in white colour is preserved. In front of the base and oriented to the left, there are the signs ' $m j$ ' and the word ' $\underline{d} t$ '. They certainly refer to the formula ' $m j R^{\ulcorner} \underline{d} t$ ', 'like Re, forever'. Finally, on fragment inv. no. 14841 (Fig. 1d), it is possible to identify the left hand holding a sign ' $n h$ ' and the two staffs, as well as part of the mummiform legs, belonging to the same figure. ${ }^{28}$

${ }^{28}$ The sign ' $n h$ ' held by the king is not common in this kind of scenes, and is not attested on similar representations from Deir el-Bahari. However, it is depicted, for example, in the scene representing king Amenemhat I inside the double pavilion on the east side of his pyramid temple at Lisht (Simpson 1963: Pl. VIII). Unfortunately, this block (JE 40484) was found, together with other reliefs belonging to this king, reused as foundations, and its original context is lost. 
These reliefs probably originally depicted a scene with a double pavilion, as the poles seen on inv. no. 1049 indicate, where the king was represented alternatively with a White and Red Crown. This kind of symmetrical scene that shows the king in the Heb Sed robe sitting on a throne inside a double pavilion and wearing the land crowns appears to have been considered as the main event of the festival. ${ }^{29}$ It would have often served as condensed ritual iconographic symbol for the whole ceremony, ${ }^{30}$ but without having to be directly related to the actual depiction of the Heb Sed ceremony. Thus, it was made clear that the ruler has overcome regeneration and took the divine kingship on the double throne for eternity. ${ }^{31}$ The beard and crowns and the attributes held by the king - the sceptre and flail - implicate the same, while the sign ' $n h$ ' may embody the divine nature that the royal figure has reached after regeneration. Similar decorative arrangements are quite common in temples of all periods, usually placed on lintels or above a door. ${ }^{32}$ The closest parallels are the above-mentioned reconstructions of doorways leading to rooms associated with the royal cult of Thutmose I and Hatshepsut at Deir el-Bahari. For the Eighteenth Dynasty, two similar representations are documented for Amenhotep I at Karnak, ${ }^{33}$ and at his MenIset temple at Qurna, ${ }^{34}$ and for Amenhotep III on the eastern wall of the Birth Room at Luxor temple. ${ }^{35}$

Almost nothing is preserved about the details that once were represented outside the pavilion. A standard with human arms holding a year-stick which could be seen at Deir el-Bahari or other scenes of this type has not been identified. The orientation of the formula ' $m j R^{\complement} \underline{d} t$ ' preserved on fragment inv. no. 893 (Fig. 1c), may indicate that it belonged to a typical vertical inscription referring to the king and recited by the Wepwawet-standard or, most probably, by Iunmutef. ${ }^{36}$ Likewise, the other formula placed at the back of the king's figure (Fig. 1b) correspond to the one usually found inside the pavilion. Two elements, the White Crown and the orientation of the figure, reveal that the scene could have been placed on the east side of a lintel of a doorway placed on an east-west axis, as it is the case in Hatshepsut's temple at Deir el-Bahari or Amenhotep III's scene at Luxor. If so, the White Crown would appear on the south side. This would fit perfectly with the double display of gestures and rituals symbolising the renewal of power in Upper and

29 Rummel 2006: 393; 2010: 158, 161; Bleeker 1967: 98, 107-108.

${ }^{30}$ In some Heb Sed episodes, the king might have sit in one pavilion while the other was empty, because the scene is focused on the ritual undergone either for Upper or for Lower Egypt. See, for example, scenes belonging to the Heb Sed festival represented in the Temple of Niuserre (Bissing, Kees 1928: 11, 13, 24, 27). However, lack of stairs in the area of the dais (cf. Fig. 7) enabled us to exclude this possibility in the case of the discussed representation.

31 Rummel 2010: 158-160.

32 Arnold 1997. For a listing of these representations, see: Hornung, Staehelin 2006: 13-32.

33 Chevrier 1947: Pls 26-27.

34 Urk. I, 50; Winlock 1917: 11-15, Pls 3-4; Sethe 1921: 31-35; Van Siclen III 1980: Fig. 7.

35 PM II², 327 (155), 3; Schwaller De Lubicz, Miré, Miré 1982: 63.

36 Iunmutef is placed in front of the pavilion, for example, in the scene of Amenhotep III in Luxor temple (PM II², 327 (155), 3; Schwaller De Lubicz, Miré, Miré 1982: 63) or in the northern doorway in the Temple of Amenemhet III at Bubastis (Farid 1964: 85, Pl. X; Tietze, Abd El Maksoud 2004: 19). 


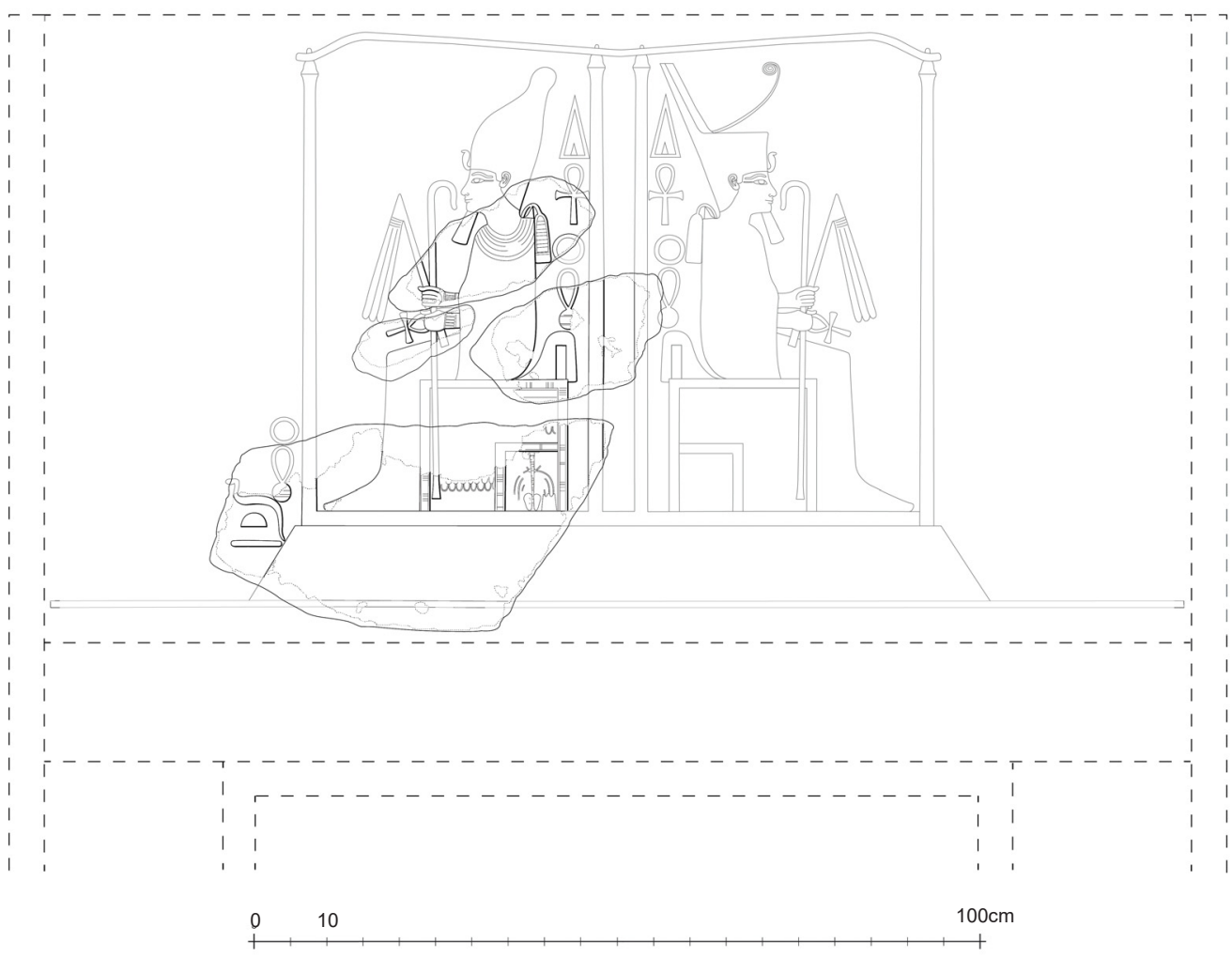

2. Possible reconstruction of the double pavilion scene (Drawing: L. Chapon (c) Thutmosis III Temple Project)

Lower Egypt, respectively. ${ }^{37}$ However, it is also possible that the scene was to be found on a doorway placed on a north-south axis. ${ }^{38}$

The scene (Fig. 2) measures at least around $120 \mathrm{~cm}$ width, including the inscription placed outside the pavilion. Hence, it is slightly smaller than the Deir el-Bahari parallels. However, if we consider that the discussed scene was placed over a doorway, it is expected that on each side of the double pavilion more elements would be represented. Therefore, if the width of the entrance proper had a minimum of $100 \mathrm{~cm}$ and on each jamb there was space for a column of inscription, the scene would have probably been at least $150 \mathrm{~cm}$ wide. However, if there was only one column of inscription, there would not have left much space for more elements outside the pavilion. The height of the scene was at least $80 \mathrm{~cm}$ from the black baseline on which the dais is laying to the top

37 Bonhême, Forgeau 1988: 297-298.

38 In that case, it is probable that the double pavilion may have been included on the southern side due to the fact that the west prevails over the east, as well as the south over north (Posener 1965), so that the king wearing the White Crown could have been oriented towards the west. 

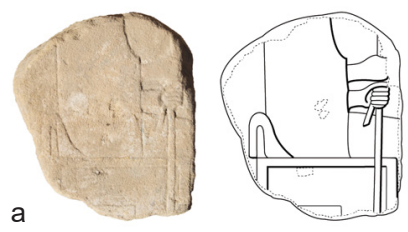

0

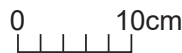

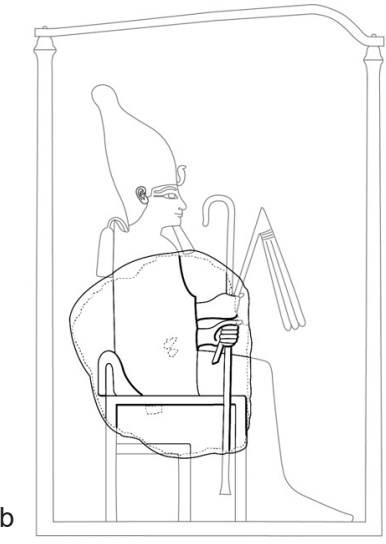

3. Enthroned figure in the Heb Sed robe: a. block inv. no. 726; b. possible reconstruction (Phot. and drawing: L. Chapon (C) Thutmosis III Temple Project).

of the pavilion..$^{39}$ The black baseline corresponded to the bottom of the scene. Regarding the white area under it (Fig. 1c), two options are possible. On the one hand, it may have belonged to the border delimiting the decoration above the lintel, which may have included inscriptions, as it is the case in Hatshepsut's temple at Deir el-Bahari. ${ }^{40}$ On the other hand, the double pavilion may have been depicted on the lintel proper. In that case, the white area should be linked to the frame of the door. ${ }^{41}$

\section{THE KING SITTING ON A THRONE}

The king is once more depicted in the Heb Sed robe sitting on a throne on fragment inv. no. 726 (Fig. 3a). He is holding the $n h 3 h 3$-flail and a scepter, which is unfortunately destroyed. Thus, it might be the $h k 3$-scepter or the ${ }^{\top} w t$-stick. The polychrome has almost disappeared, only some yellow colour and red borderline are preserved on the throne. Even if the representation is oriented towards the right, so inversely to the one discussed above, it does not belong to the same scene since the scale is different: on the previous reliefs the king's figure, about $38 \mathrm{~cm}$ high, is smaller. Furthermore, in this case, the king's back is resting directly against the backrest throne. The possibility that the enthroned figure represented on this relief was placed on a royal barque taking part in a river procession, similar as in the Temple of Hatshepsut at Deir el-Bahari or the Chapelle Rouge at Karnak, seems improbable as no rope could be distinguished in the king's hand. Further reconstruction

\footnotetext{
39 The door over which this scene was represented was probably not very wide. It is, however, difficult to identify the exact entrance where the scene was placed, due to the state of temple preservation.

${ }^{40}$ Karkowski 2001: Fig. 11.

${ }^{41}$ This is the case, for example, in Amenhotep I's Men-Iset scene (Urk. IV, 50; Winlock 1917: 11-15, Pls 3-4; Sethe 1921: 31-35; Van Siclen III 1980: Fig. 7).
} 

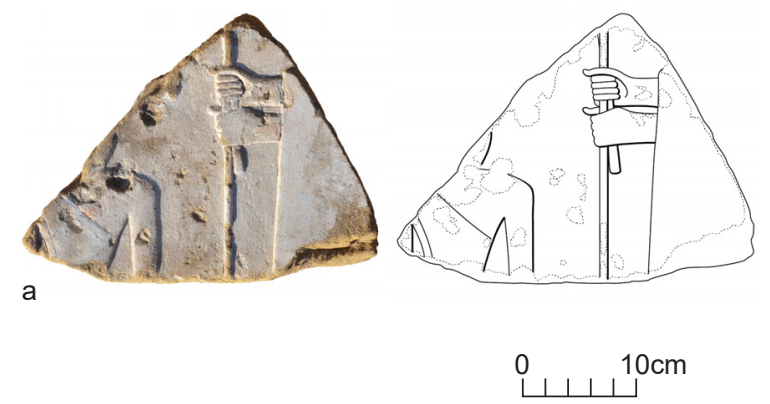

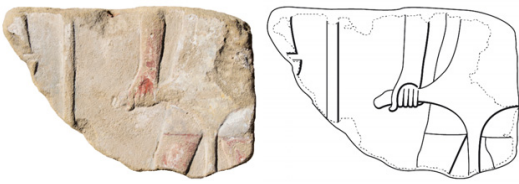

b

4a. King standing in the Heb Sed robe following Iunmutef, block inv. no. 1758; b. lower part of Iunmutef, block inv. no. 1352 (Phot. and drawing: L. Chapon (C) Thutmosis III Temple Project).

of the composition or context of the scene is problematic, due to the state of preservation of the relief. However, it is most probable that the king's figure was originally inside a pavilion (Fig. 3b). The ' $w t$-stick has been chosen for the hypothetical reconstruction since it has already been documented together with the $n h 3 h 3$-flail in the double pavilion scene described above. ${ }^{42}$

\section{THE KING STANDING BEHIND IUNMUTEF}

Already published by Herbert Ricke, ${ }^{43}$ fragment inv. no. 1758 (Fig. 4a) shows the king standing in the Heb Sed robe oriented to the left, holding the $n h 3 h 3$-flail and the $h k 3$-scepter or the 'wt-stick. A second figure precedes him, most likely Iunmutef, although only the upper right part of his body is preserved. In addition, inv. no. 1352 (Fig. 4 b) $)^{44}$ seems to correspond to the lower body of the same figure. On the same fragment, to the left, a vertical line and part of two signs, most probably ' $n b$ ' and ' $d d$ ', are preserved. The polychrome of both blocks is quite damaged but recognisable on some areas, as on Iunmutef's body and on the leopard skin.

A similar scene showing the king standing in the Heb Sed robe following Iunmutef is preserved in the Akh-menu. They are heading towards the previously mentioned scene of the shooting of arrows to the four cardinal points ${ }^{45}$ Another parallel is dated to the reign of Amasis. ${ }^{46}$ On the Akh-menu's scene, the king holds the $w 3 s$-scepter, while Amasis holds the $n h 3 h 3$-flail and the $h k 3$-scepter. Iunmutef is one of the key elements, even if not essential, of Heb Sed iconography. As in other royal contexts, he acts as medium through which the

\footnotetext{
42 The $w 3 s$-sceptre is also attested together with the $n h 3 h 3$-flail. See, for example, the scenes in the temple of Semna: Caminos 1998: Pl. 57.

43 Ricke 1939: Pl. I [d]. See also: Martínez Babón 2015: 249, Fig. 5.

${ }^{44}$ This fragment was also found in the Weigall-Ricke Magazine.

${ }^{45}$ LD III, Pl. 36b; PM II ${ }^{2}$, 113; Barguet 1962: 165-166; Hornung, Staehelin 2006: 60; Rummel 2010: 160-161, cat. no. 15.

${ }^{46}$ Habachi 1942: 385, Fig. 105.
} 


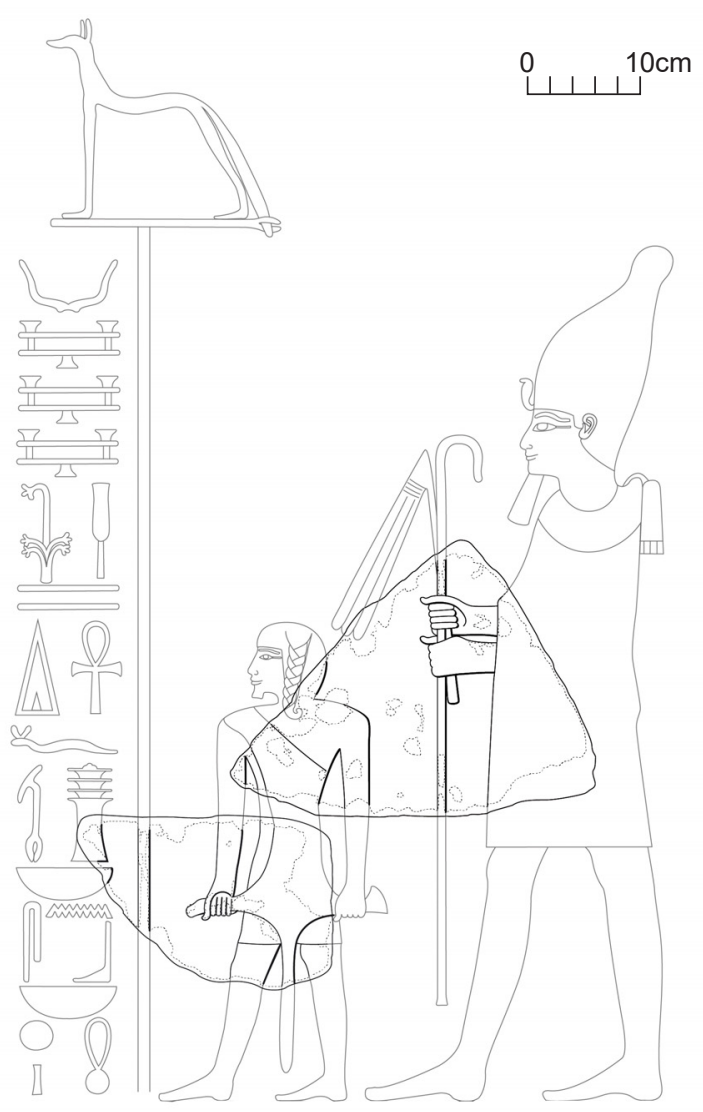

5. Reconstruction of the scene showing the king standing in the $\mathrm{Heb}$ Sed robe following Iunmutef(Drawing: L. Chapon (C) Thutmosis III Temple Project).

king may accomplish the rituals and be rejuvenated. ${ }^{47}$ Especially from Hatshepsut time, the attestation of this figure increases considerably. This fact may be related to his growing significance in the development of the theology and rituals of divine kingship. He acts as the ritual officiant who provided for the revival and renewal of the ruler's divine nature. ${ }^{48}$

Contrary to the above mentioned scenes of Amasis and Thutmose III, the figures preserved on the reliefs discovered in the Henket-Ankh are oriented to the left. They are also smaller than above-cited analogies, so that the king would have been about $74 \mathrm{~cm}$ high and Iunmutef about $41 \mathrm{~cm}$. The vertical element seen on fragment inv. no. 1352 may correspond to the pole of a standard. It was likely a Wepwawet-standard or it may have been combined with the royal placenta, being both represented separately in the Akh-menu. The signs visible left to this vertical element may belong to a vertical inscription, which is usually

${ }^{47}$ It should be noted that the linen used for the Heb Sed robe, together with other important elements as incense and oil, is often offered to the king by Iunmutef, who is represented in the recitation gesture in front of the throne's dais (Rummel 2006: 383; 2010: 158-161).

48 Rummel 2010: 81-83. 


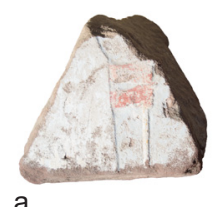

a

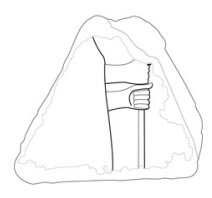

.

\begin{abstract}
.
\end{abstract}

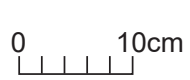

\title{
b
}

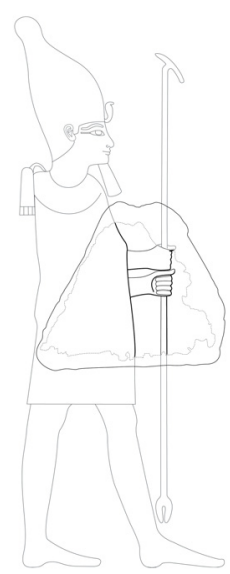

6. Standing king in the Heb Sed robe: a. block inv. no. 999; b. reconstruction (Phot. and drawing: L. Chapon (C) Thutmosis III Temple Project).

found in temple contexts in front of the Wepwawet-standard. Despite the similarities with the aforementioned parallels, it is not possible to assert clearly the scene to which the king was directed. The ${ }^{\top} w t$-stick is again chosen for the hypothetical of reconstruction (Fig. 5).

\section{THE STANDING KING}

Relief inv. no. 999 (Fig. 6a) shows part of the king's figure, standing and oriented towards the right. Although the area above the hands is destroyed, it is possible to deduce that the king was holding a single insignia, probably the $h k 3$-scepter, but it may also have been the ${ }^{\top} w t$-stick or even the $w 3 s$-scepter ${ }^{49}$ The polychromy is partially preserved on the robe and hands, as well as on the attribute. As no other relief could be so far associated to this scene, it is difficult to reconstruct how it originally looked like. The king's figure was about $49 \mathrm{~cm}$ high (Fig. 6b), so the scale was similar to the representation on fragment inv. no. 726 (Fig. 3).

\section{IUNMUTEF IN FRONT OF A PAVILION WITH STAIRS}

Another representation of Iunmutef is preserved on fragment inv. no. 1288 (Fig. 7a). His arms are falling loosely along the body, which indicates he was holding the edges of a leopard skin. The figure wears a blue necklace as well as a yellow-orange leopard skin with black spots and has some kind of blue-white-red band on the upper part. Originally the figure had to be bigger (about $51 \mathrm{~cm}$ high) than the one shown on fragments inv. nos 1758 and 1352 (Figs 4-5). This suggests that these scenes did not belong to the same group. Behind the figure, a part of some stairs is preserved, which may have started just under

\footnotetext{
49 The $w 3 s$-scepter has been chosen for the hypothetical reconstruction as an example.
} 

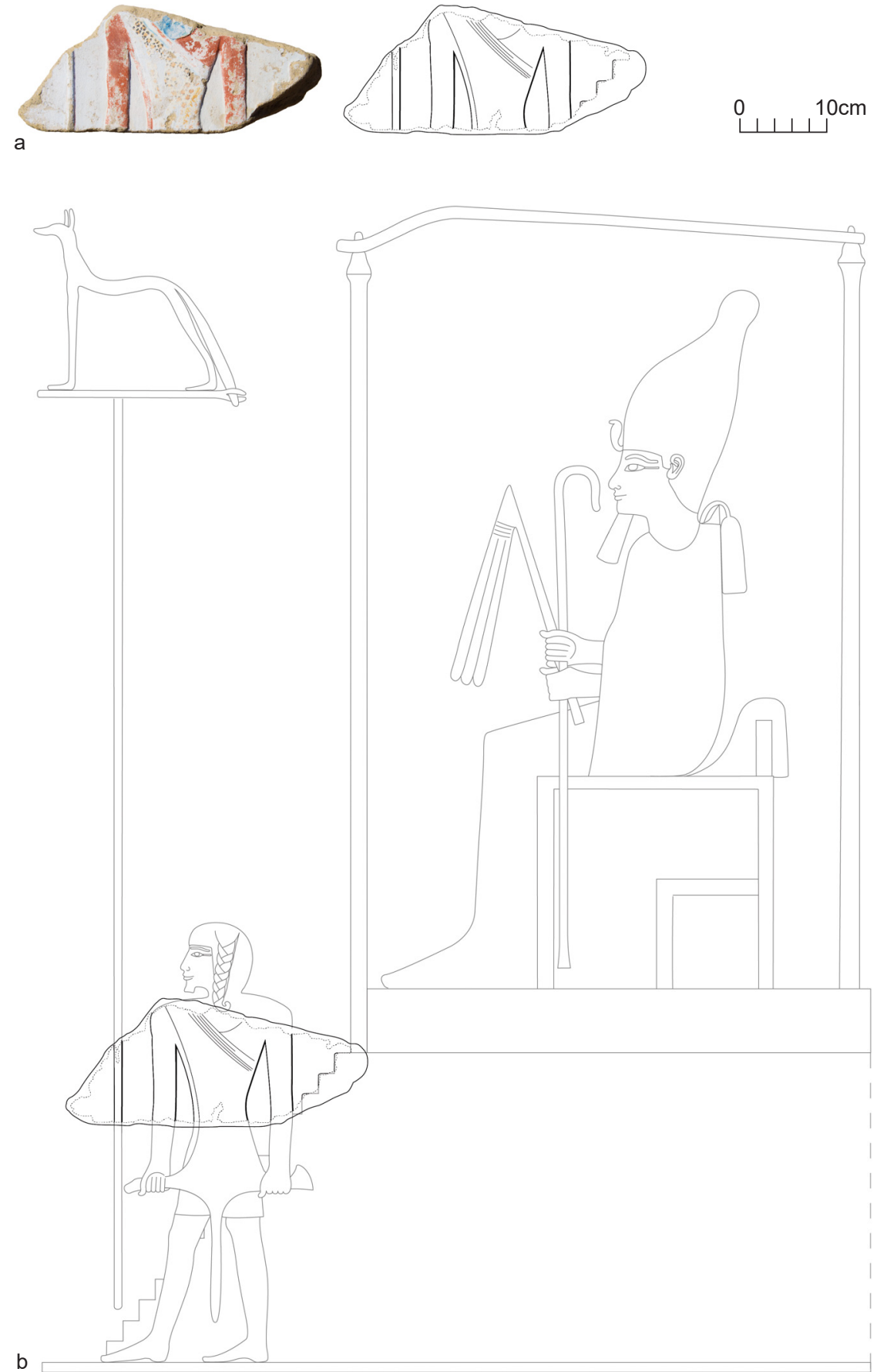

7. Iunmutef in front of a pavilion with stairs: a. block inv. no. 1288; b. reconstruction (Phot. and drawing: L. Chapon (C) Thutmosis III Temple Project). 
the level of Iunmutef's shoulder and have ended at the level of the feet. It was probably part of a dais on which a pavilion was placed. In front of Iunmutef, a vertical line appears that may have belonged to a standard, most likely the Wepwawet one.

Scenes where Iunmutef is placed in front of a pavilion with stairs may be seen in different episodes belonging to the Heb Sed, in which the king is visiting various chapels or he is outfitted with the Heb Sed robe to be successively placed on the throne. However, on Niuserres's scenes in his solar temple at Abu Ghurab ${ }^{50}$ and on Osorkon's reliefs at Bubastis ${ }^{51}$ where Iunmutef with the same gesture is placed in front of the pavilion, the king is usually sitting inside the pavilion in the Heb Sed robe. Therefore, we may suppose that this was also the case for the Henket-Ankh's scene. However, we cannot state if he was wearing White or Red Crown. ${ }^{52}$ In the set of scenes represented in the Akh-menu, the king is at least twice represented with the Heb Sed robe inside a pavilion placed on a dais with stairs. ${ }^{53}$ Unfortunately, it is not possible to state if the discussed scene from the HenketAnkh showed a double or a single pavilion (Fig. 7b). ${ }^{54}$

\section{Fragments PRESERVING HEB SED SIGNS}

In addition, some sandstone fragments containing isolated Heb Sed signs have been documented in both bas- and sunk relief. For instance, inv. nos 1284 and 4300, in sunk relief, and inv. no. 1397, in bas-relief, pertain most probably to the horizontal lower decoration of pillars (Fig. 8a-b, d). Specific formula, such as ' $z p$ tpy $h b-s d$ ', 'the first time/occasion of the Heb Sed' or 'zp tpy whm hhb-sd', 'the repetition of the Heb Sed' ${ }^{55}$ have often been used as historical sources to prove the first celebration or actual planning of the festival ${ }^{56}$ However, these formulas may in fact correspond to a standard repeated hyperbolical construction used to express the wish to celebrate one or more festivals in the future, providing eternal royal regeneration. ${ }^{57}$ Pillars were the most common places chosen to place this stereotyped formula. ${ }^{58}$

${ }^{50}$ Bissing, Kees 1928: 13, 23, 24.

${ }^{51}$ Kuraszkiewicz 1996. See also: Uphill 1965.

${ }_{52}$ In the scene reconstructed on the basis of fragment inv. no. 1288, the White Crown has been chosen only as an example. Since it cannot be stated if the scene corresponds to Lower or to Upper Egypt, we cannot reconstruct whether the Red or the White Crown was here represented. However, the White Crown generally prevails over the Red one.

${ }^{53} \mathrm{~L} D$ III, Pl. 36b.

${ }^{54}$ No double pavilion is represented in the Akh-menu or in Osorkon's reliefs, while they are common in Niuserre's temple, even if in some cases one of the pavilions is empty.

${ }_{55}$ Murnane 1981: 370-374; Hornung, Staehelin 2006: 11.

${ }^{56}$ Wente, Van Sinclen III 1976: 227; Murnane 1981: 369-376; Kitchen 1973: 302, 305.

${ }^{57}$ Bonhême, Forgeau 1988: 289; Hornung, Staehelin 1974: 63-65; 2006: 10-12, 41-42; Hornung 1991: 169 171. For a compilation of New Kingdom references including Heb Sed wishes, see also: Birkstam 1974: 21-23.

${ }^{58}$ Since these formulas used to be placed on pillars, Donald B. Redford (Redford 1986: 180) entitled them 'Pillar Benediction'. For the use and function of these pillars in Temples of Millions of Years, see: Leblanc 2010: 69-89. Close parallels may be found in Hatshepsut's temple at Deir el-Bahari on pillars of the Middle Portico (Naville 1898: Pls LXV-LXVI) and of the Upper Portico (Karkowski 1980: 49, Fig. 5). Pillars placed in the Heret-ib of the Akh-menu show also the same features (Pecoil, Baud, Beaux 2000: Pls 17-78). 

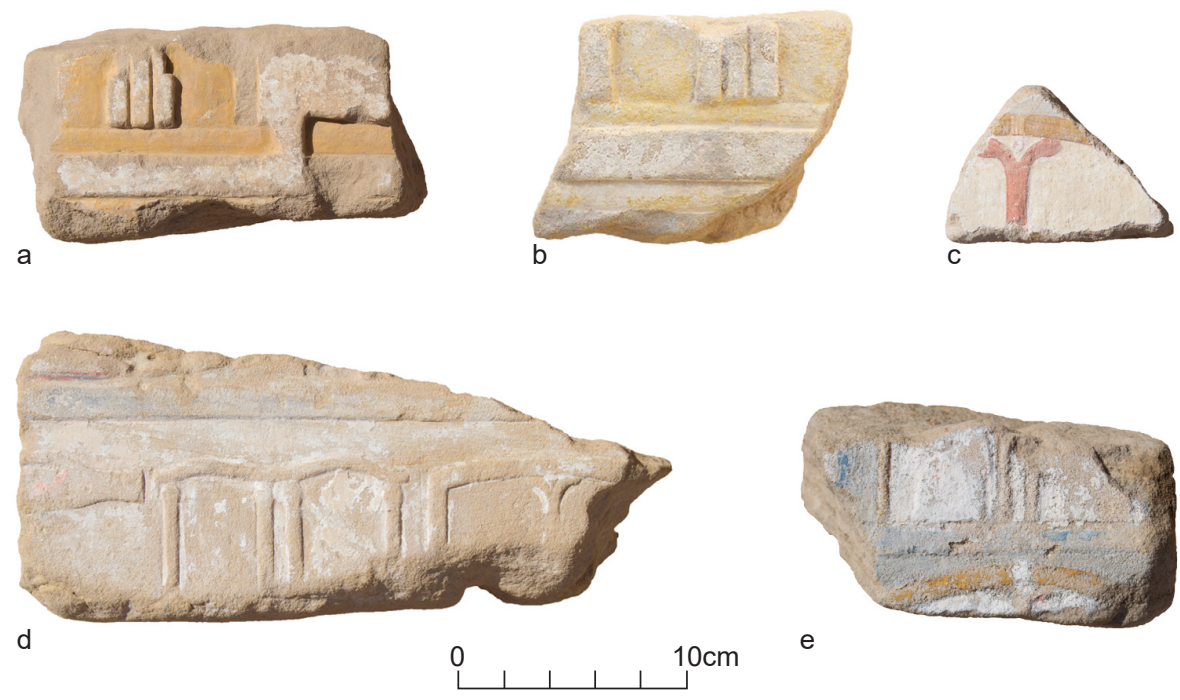

8. Some fragmentary block with Heb Sed signs: a. inv. no. 1284; b. inv. no. 4300; c. inv. no. 11648; d. inv. no. 1397; e. inv. no. 2265 (Phot. L. Chapon (C) Thutmosis III Temple Project).

a
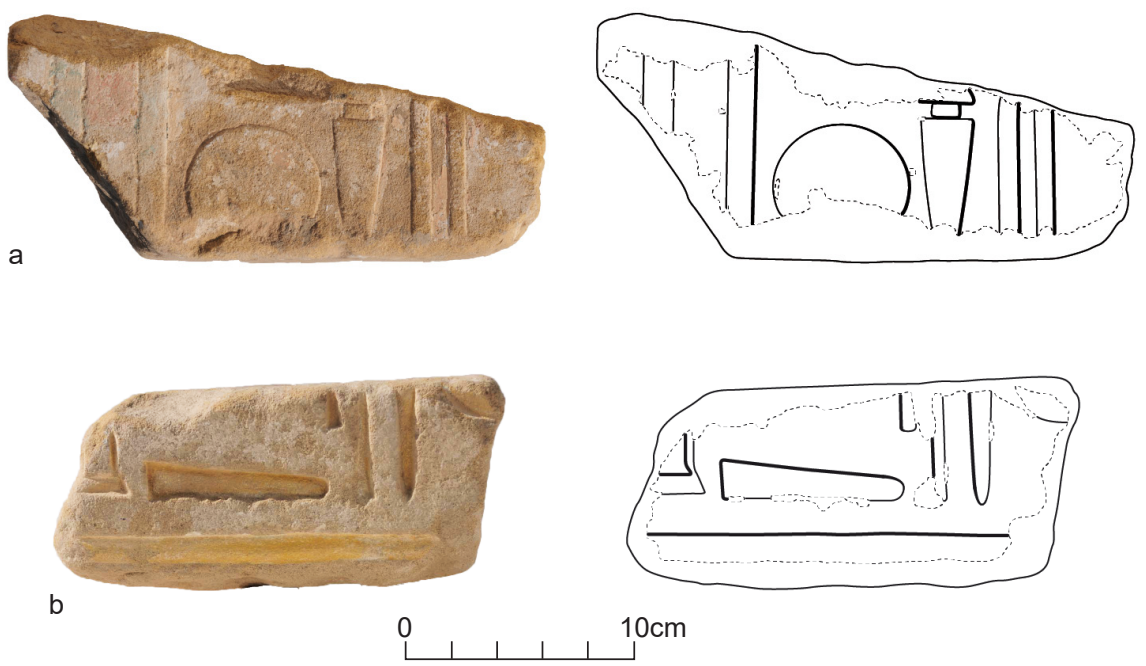

9. Two fragmentary blocks with part of formula ' $z p t p y$ h $h$-sd': a. inv. no. 138; b. inv. no. 1534 (Phot. and drawing: L. Chapon (C) Thutmosis III Temple Project).

Among the sandstone blocks discovered in the Henket-Ankh, only the form ' $z p$ tpy $h b$-sd' has been identified (Fig. 9), as happens at Deir el-Bahari and the Akh-Menu. The original placement of other fragments, as inv. nos 2265 and 11648 (Fig. 8c, e), is more difficult to reconstruct, as these elements could be found in many scenes connected with the royal sphere. 


\section{CONCLUSIONS}

The king in the Heb Sed robe was represented at least five times in the Temple of Millions of Years of Thutmose III. The first scene, comprising fragments inv. nos 930, 1049, 893 and 14841 (Fig. 2), belongs unmistakably to a double pavilion. It could have been situated on the eastern upper area of a doorway situated on an east-west axis, so that the White Crown would have been placed on the southern side. However, it is also possible that the double pavilion was placed on a doorway situated on a north-south axis. Similar scenes appear to not be directly connected to the Heb Sed ceremony. They were, as was probably the case for the one that occurred in the Henket-Ankh, almost certainly related to the symbolic programme of the temple aiming to suggest the eternal regeneration of the royal office personified by the reigning king.

The other reliefs could belong to a second set of connected scenes or to different iconographic contexts. It seems likely that inv. nos 1758 and 1352 showing the king following Iunmutef (Fig. 5) and inv. no. 1288 representing again Iunmutef in front of a dais with stairs (Fig. 7b) may belong to episodes of the Heb Sed ceremony. However, these two reliefs are not in the same scale, so that they were probably not represented in scenes directly related. In this regard, the scenes represented in the Akh-menu were linked to the Heb Sed ritual in close connection with the Sokarian cycle. Actually, this complex was also considered as a Temple of Millions of Years aimed to the eternal regeneration of the king. ${ }^{59} \mathrm{It}$ is expected that Thutmose III would have also decided to represent a set of ceremonies connected to this important ritual in his temple of Western Thebes. Finally, the figures preserved on inv. nos 999 and 726 show a similar scale (Figs 3b, 6b), but much smaller than the one found on preceding fragments. Thus, it is possible that they may have belonged to the same scene showing small size king's figures or, at least, similar ones. Unfortunately, it is much more problematic to deduce their original context.

Thutmose III's possible Heb Sed celebrations have repeatedly been mentioned and discussed in Egyptological literature. However, the reliable sources are very few, which consists of some inscriptions, statues and iconographic representations. The scholars base in this matter on different evidence. Firstly, the construction of the Akh-menu, started near the end of twenty regnal year after Hatshepsut's disappearance. In this case, the celebration of the festival would have occurred in anticipation of the Heb Sed of thirty regnal year, date when the Akh-menu was probably already finished. ${ }^{60}$ The stela of Sennefer at el-Bersha has been considered to be a possible allusion to a celebration of the ceremony in year $33 .{ }^{61}$ The obelisk of Heliopolis, today in London, speaks of erecting of the obelisk ' $m$ zp. $f$ 3- $n w$ $h b$-sd', 'on his third occasion of the Heb Sed', which has been understood by scholars as commemoration of a celebration of the Heb Sed in year $40 .{ }^{62}$ Finally, the text inscribed in

\footnotetext{
${ }^{59}$ Ullmann 2002: 82-83; Laskowski 2006: 192-195; Masquelier-Loorius 2017.

${ }^{60}$ Murnane 1981: 373, 375-376; Haeny 1970: 13.

${ }^{61}$ Urk. IV, 597.

${ }^{62}$ Urk. IV, 590, 15.
} 
the 'Reposoir de barque' of Thutmose III in front of the sacred lake and to the south-east of the VII Pylon mentions 'zp tpj whm hlb-sd', 'the first time/occasion of renewing the Heb Sed', without any date. ${ }^{63}$ Other similar inscriptions occurred on pillars beside the V Pylon ${ }^{64}$ and in the Djeser-Akhet temple at Deir el-Bahari. ${ }^{65}$

On the basis of epigraphic data and the function attributed to the Akh-menu, it has been suggested that Thutmose III could have celebrated as many as six festivals, ${ }^{66}$ apart from the one attributed to Hatshepsut. ${ }^{67}$ However, according to other scholars, mainly Eric Hornung and Elisabeth Staehelin, the exact number is uncertain, and it is even not possible to undoubtedly ascertain any celebration during the reign of Thutmose III through the preserved evidence. ${ }^{68}$ Some standard hyperbolical formula may have been used to express the wish to celebrate one or more festivals in the future. Furthermore, iconographic representations, for instance, from the Akh-menu may be more everlasting enactments than actual representations of a real ceremony. ${ }^{69}$ Finally, it seems that in Deir el-Bahari's scenes with the kings in the Heb Sed robe could actually have been associated to other royal contexts.

As this kind of representations was recurrently part of the ceremonial iconographic programme of temples, it is then difficult to discern if the fragmented reliefs discovered in the Temple of Thutmose III correspond to actual events or are just elements of propaganda. Moreover, apart from some isolated Heb Sed signs and common formula, no inscriptions, which could be directly connected to this iconographic theme, have been discovered in the temple. As we stated previously, specific formula, such as 'zp tpy $h b-s d$ ', 'the first time/occasion of the Heb Sed', may have been used as a standard repeated hyperbolical construction used to express the wish to celebrate one or more festivals in the future, providing eternal royal regeneration. It is probable that the reconstructed scenes from the Henket-Ankh had the same purpose. Like the ǰs $d$-tree scene - also documented in the Henket-Ankh, ${ }^{70}$ Heb Sed iconography would provide symbolic support for the renewal and confirmation of the king's authority.

It cannot also be excluded that other scenes where the king is shown in the Heb Sed robe existed in the Henket-Ankh, for example similar to those attested at Hatshepsut's temple

63 Urk. IV, 595, 11.

64 Urk. IV, 596, 1.

65 Lipińska 1977: 49.

${ }_{66}$ Mainly Murnane 1981: 373, 375-376. For a discussion about the celebration of the ritual in regnal year 30, see: Hornung, Staehelin 1974: 56, 62-65; 2006: 9-12, 39-40.

${ }^{67}$ Some scholars, e.g. William J. Murnane (Murnane 1981: 372), Suzanne Ratié (Ratié 1979: 201-204) and Jürgen von Beckerath (Beckerath 1997: 15-20), support the idea that the 'first time/occasion of the Heb Sed' inscribed on the obelisk at Karnak (Urk. IV, 358, 11-359, 1-2) are a proof of Hatshepsut's Heb Sed in year sixteen of her reign. However, they may also express a mere wish (Hornung, Staehelin 2006: 63-65). For a discussion, see: Karkowski 2001: 109-111.

${ }^{68}$ Hornung, Staehelin 1974: 31-32, 53.

${ }^{69}$ Hornung, Staehelin 2006: 51-61; Refai 2000: 48-52. According to some scholars, a number of requirements have to be met to talk about real celebrations of the Heb Sed. See: Bonhême, Forgeau 1988: 289-292; Hornung, Staehelin 2006: 12.

70 Chapon 2016. 
at Deir el-Bahari or the Chapelle Rouge, representing the king inside a pavilion placed on the royal barque while pulling Amon's one. In fact, fragments belonging to a river sceneprobably connected to the procession of Opet or the Festival of the Valley - have been identified among sandstone blocks from the site. The back of a single pavilion shown on one fragment with two fans placed behind shares similarities with Deir el-Bahari royal barques. Finally, several fragments preserving part of pavilions and Wepwawet-standards have also been discovered. On one of them, the standard is oriented in the opposite direction than the pavilion. The second preserves two registers. The lower one shows the standard heading towards the pavilion, while nothing remains from the upper register. Possibly, this is part of a scene of presenting standards to the enthroned figure of the king.

Unfortunately, there is no preserved cartouche that may be associated to the king's figures in the Heb Sed robe. In some temple's, divinised ancestors are depicted wearing this garment, as it is the case of Thutmose I at Deir el-Bahari or Sesostris III at Semna. However, most often the figure in the Heb Sed robe is the ruler responsible for the construction of the temple. Therefore, this was most probably Thutmose III himself that was represented in his Temple of Millions of Years. As the most direct royal ancestor, Thutmose II could also have been depicted in this kind of scene, even if the presence of Thutmose I should not be completely excluded. In the Henket-Ankh, this king must have been included in at least one scene, because one fragment belonging to an offering scene has been documented with his cartouche. Moreover, Hatshepsut's name has been documented on some sandstone fragments from this temple, as well as together with Thutmose I's cartouche on mudbricks from the enclosure wall of the temple. ${ }^{71}$ Although the queen may have been in some way incorporated within the temple decorative program in the first construction phase - to be probably dated to the coregency ${ }^{72}$ - it is however implausible that she would be represented in further works that occurred during the sole reign of Thutmose III. As the reliefs are fragmented and their original location lost, it is impossible to infer to which decorative stage of the temple they belong. Anyway, the temple was almost certainly devoted to the cult of Thutmose III from the beginning and it is dubious that Hatshepsut would have been represented in this kind of scene.

The state of preservation of the above-analysed sandstone blocks does not permit an ascription of them precisely to a specific room or area within the temple and make their interpretation somehow problematic. ${ }^{73}$ Therefore, to place these reliefs in the decorative program of the temple is very difficult. The reconstructed double pavilion should be placed in rooms connected to the royal cult on the southern side of the temple, as it is the case, for example, in Deir el-Bahari or Amenhotep III at Luxor temple. It can be suggested that the

71 Ricke 1939: 8, no. 15.

72 Seco Álvarez 2012: 68.

73 As Marie-Ange Bonhême and Annie Forgeau (Bonhême, Forgeau 1988: 293) stated, most of the preserved Heb Sed representations are known from scattered blocks, without clearly related inscriptions. Therefore, their reconstructions always will be only hypothetical. 
scenes that are most probably connected to the Heb Sed ceremony could have also been located on the southern side of the temple, as is attested in the Akh-menu. However, the king in the $\mathrm{Heb} \mathrm{Sed}$ robe, taking part in different rituals related to the royal sphere may have been represented also in other areas of the temple. In any case, despite the obvious difficulties in the interpretation of these fragments, they attest the complexity of the symbolic and ritual decorative programme, as well as the quality and polychrome of the reliefs, that once existed in the Temple of Millions of Years of Thutmose III.

\section{Acknowledgments}

The Project of the Temple of Millions of Years of Thutmosis III has been financed mainly by the Botin Foundation, the Santander Bank and CEMEX group. This paper is a subpart of a doctoral thesis that was possible to carry out thanks to the funding of Santander Universidades.

\section{References}

Arnold, D. 1997: Royal Cult Complexes of the Old and Middle Kingdom, [in:] Shafer, B. (Ed.), Temples of Ancient Egypt, London-New York, 31-85

Barguet, P. 1962: Le temple d'Amon-Rê à Karnak. Essai d'exégèse, RAPH 21, Le Caire Beckerath, J. von 1997: Zum Jubiläum der Hatschepsut, [in:] Aksamit, J., Dolińska, M., Majewska, A., Niwiński, A., Rzepka, S., Szafrański, Z.E. (Eds), Essays in Honour of Prof. Jadwiga Lipińska, Warsaw Egyptological Studies I, Warsaw, 15-20

Birkstam, B. 1974: Given Life Like Re Eternally - A Royal Epitheton, [in:] Brunnsaker, S., Nordström, H.A. (Eds), From the Gustavianum Collections in Uppsala, Boreas 6, Uppsala, 15-35

Bissing, F.W., Kees, H. 1928: Das Re-Heiligtum des Königs Ne-woser-Re (Rathures), vol. III. Die große Festdarstellung, Leipzig

Bleeker, C.J. 1967: Egyptian Festivals: Enactments of religious renewal, Leiden

Bonhême, M.A., Forgeau, A. 1988: Pharaon. Les secrets du pouvoir, Paris

Burgos, F., Larché, F. 2006: La chapelle Rouge. Le sanctuaire de barque d'Hatshepsout 1, Paris

Caminos, R.A. 1998: Semna-Kumma I: The Temple of Semna, London

Chapon, L. 2016: Une possible représentation de l'arbre $j \check{d} d$ dans le temple de Millions d'Années de Thoutmosis III à Thèbes-Ouest, BIFAO 116, 47-56

Chevrier, H. 1947: Rapport sur les travaux de Karnak (1946-1947), ASAE XLVII, 161-183

Daressy, G. 1926: Le voyage d'inspection de M. Grébauten en 1889, ASAE XXVI, $1-22$

Davies, V. 2004: Hatshepsut's Use of Thutmosis III in her Program of Legitimation, JARCE XLI, 55-66

Farid, A. 1979: Blocks from a Temple of Thutmosis III at Dakka, ChronEg 54, 1-7

Farid, Sh. 1964: Preliminary report on the excavations of the Antiquities Department at Tell Basta (season 1961), ASAE LVIII, 85-98 
Habachi, L. 1942: Sais and its monuments, ASAE XLII, 369-407

Haeny, G. 1970: Basilikale Anlagen in der ägyptischen Baukunst des Neuen Reiches, $B \ddot{A B A}$ 9, Wiesbaden

Hornung, E. 1991: Sedfest und Geschichte, MDAIK 47, 169-171

Hornung, E., Staehelin, E. 1974: Studien zum Sedfest, AegHelv 1, Geneva

Hornung, E., Staehelin, E. 2006: Neue Studien zum Sedfest, AegHelv 20, Basel

Karkowski, J. 1980: An Archaeological Description of the Decoration of Osirid Pillars of the Upper Portico of the Temple of Hatshepsut at Deir el-Bahari, [in:] Krzyżanowski, L. (Ed.), The Temple of Queen Hatshepsut. Results of the Investigations and Conservation Works of the Polish-Egyptian Archaeological and Preservation Mission 1972-1973, Warsaw, 44-55

Karkowski, J. 2001: Pharaoh in the Heb-Sed Robe in Hatshepsut's Temple at Deir el-Bahari, EtudTrav XIX, 81-112

Kitchen, K.A. 1973: The Third Intermediate Period in Egypt, Warminster

Kuraszkiewicz, K.O. 1996: Bemerkungen zur Rekonstruktion des Jubiläumsportals Osorkons II, GöttMisz 151, 79-107

Laboury, D. 1998: La statuaire de Thoutmosis III. Essai d'interprétation d'un portrait royal dans son contexte historique, AegLeod 5, Liège

Lacau, P., Chevrier, H. 1977-1979: Une chapelle d'Hatshepsout à Karnak II, Le Caire

Laskowski, P. 2006: Monumental Architecture and the Royal Building Program of Thutmose III, [in:] Cline, E.H., O'Connor, D. (Eds), Thutmose III. A New Biography, Ann Arbor, 183-237

Leblanc, C. 2010: Les Châteaux de Millions d'Années : une redéfinition à la lumière des récentes recherches. De la vocation religieuse à la fonction politique et économique, [in:] Leblanc, Ch., Zaki, G. (Eds), Les temples de millions d'années et le pouvoir royal à Thèbes au Nouvel Empire. Sciences et nouvelles technologies appliquées à l'archéologie, Memnonia, Cahier supplémentaire 2, Le Caire, 46-53

Lipińska, J. 1977: The Temple of Tuthmosis III, Architecture, Deir el-Bahari II, Warsaw Martínez Babón, J. 2015: Aspectos epigráficos e iconográficos del Templo de Millones de Años de Tutmosis III, [in:] Seco Álvarez, M., Jódar Miñarro, A. (Eds), Los templos de Millones de años en Tebas, Granada, 245-271

Masquelier-Loorius, J. 2017: The Akh-menu of Thutmosis III at Karnak. The Sokarian Rooms, [in:] Rosati, G., Guidotti, M.C. (Eds), Acts of the XIth International Congress of Egyptologists, Florence Egyptian Museum, Florence 23-30 August 2015, Archaeopress Egyptology 19, Oxford, 394-398

Murnane, W.J. 1981: The Sed Festival: A Problem in Historical Method, MDAIK 37, 370-376

Naville, E. 1898: The Temple of Deir el Bahari III. End of Northern Half and Southern Half of the Middle Platform, MEEF 16, London

Pecoil, J.-F., Baud, R., Beaux, N. 2000: L'Akh-menou de Thoutmosis III à Karnak. La Heret-ib et les chapelles attenantes. Relevés épigraphiques, Paris

Posener, G. 1965: Sur l'orientation et l'ordres des points cardinaux chez les Égyptiens, [in:] NAWG I, Philologisch-Historische Klasse 2, Göttingen, 69-78 
Ratié, S. 1979: La reine Hatshepsout, OrMonsp 1, Leiden

Redford, D.B. 1986: Pharaonic King-Lists, Annals and Day Books, Mississauga

Refai, H. 2000: Untersuchungen zum Bildprogramm der grossen Säulensäle in den thebanischen Tempeln des Neuen Reiches, Beitr ̈̈g 18, Wien

Ricke, H. 1939: Der Totentempel Thutmoses‘ III., B̈̈BA 3/1, Kairo

Rummel, U. 2006: Weihrauch, Salböl und Leinen: Balsamierungsmaterialien als Medium der Erneuerung im Sedfest, SAK 34, 381-407

Rummel, U. 2010: Iunmutef: Konzeption und Wirkungsbereich eines altägyptischen Gottes, SDAIK 33, Berlin-New York

Sankiewicz, M. 2010: The 'coregency' of Hatshepsut and Thutmose III in the light of iconography in the temple of Hatshepsut at Deir el-Bahari, [in:] Horn, M., Kramer, J., Soliman, D., Staring, N., Hoven, C. van den, Weiss, L. (Eds), Current Research in Egyptology 2010, Proceedings of the Eleventh Annual Symposium, which took place at Leiden University 2010, the Netherlands January 2010, Oxford-Oakville, 131-144

Schwaller De Lubicz, R.A., Miré, G. de, Miré, V. de 1982: Les temples de Karnak : contribution à l'étude de la pensée pharaonique I, Paris

Seco Álvarez, M. 2012: Trabajos Arqueológicos en el Templo de Millones de Años del Faraón Tutmosis III en Luxor, Campañas 2008-2011, Djeser 4, 64-73

Seco Álvarez, M. 2014: The Temple of Millions of Years of Tuthmosis III, EgArch 44, 21-25

Seco Álvarez, M. 2015: Latest news about the work of investigation in the Temple of Millions of Years of the pharaoh Thutmose III in Qurna, [in:] Seco Álvarez, M., Jódar Miñarro, A. (Eds), The Temples of Millions of Years in Thebes, Granada, 101-133 Seco Álvarez, M., Radwan, A. 2010: Egyptian-Spanish Project at the Temple of Thutmosis III in Luxor West Bank: Results of two Seasons, [in:] Leblanc, Ch., Zaki, G. (Eds), Les temples de millions d'années et le pouvoir royal à Thèbes au Nouvel Empire. Sciences et nouvelles technologies appliquées à l'archéologie, Memnonia, Cahier supplémentaire 2, Le Caire, 59-71

Seco Álvarez, M., Radwan, A., Martínez Babón, J., Alaeldine, A., Kamimura, E., Mora Ruedas, E., Moreno Cifuentes, M.A, Noureddine, I., Perzlmeier, C., Abu Ylazid, M.A., abd el Karim, F.Y., Abu Zaid, O., Khairi Mohamed, F. 2010: First Season of the Egyptian-Spanish Project at the Funerary Temple of Thutmosis III in Luxor, ASAE 84, 27-61

Seco Álvarez, M., Radwan, A., Martínez Babón, J., Noureddine, I., Wilson, E., Guio, A., Kamimura, E., Gamarra Campuzano, A., Mora Ruedas, E., Moreno Cifuentes, M.A., Bader, B., Pazos, F., abd el Karim, F. Y., el Nouby, E., Khairi Mohamed, F. 2012-2013: Second and Third Excavation Season of the Egyptian-Spanish Project at the Mortuary Temple of Thutmosis III at the West Bank of Luxor (2009 and 2010), ASAE 86, 329-395

Sethe, K. 1921: Beiträge zur Geschichte Amenophis IV, NAWG, [Göttingen], 101-130 Simpson, W.K. 1963: Studies in the Twelfth Egyptian Dynasty: I-II, JARCE II, 53-63 
Sourouzian, H. 1994: Inventaire iconographique des statues en manteau jubilaire de l'Époque thinite jusqu'à leur disparition sous Amenhotep III, [in:] Berger, C., Clerc, G., Grimal, N. (Eds), Hommages à Leclant I, Études pharaoniques, BiEtud 106, Le Caire, 499-530

Tietze, C., Abd El Maksoud, M. 2004: Tell Basta. Ein Führer duch das Grabungsgelände, Potsdam

Ullmann, M. 2002: König für die Ewigkeit, Die Häuser der Millionen von Jahren, Eine Untersuchung zu Königskult und Tempeltypologie in Ägypten, Wiesbaden

Uphill, E.P. 1961: A joint Sed-Festival of Thutmose III and Queen Hatshepsut, JNES XX, 248-251

Uphill, E. 1965: The Egyptian Sed-Festival Rites, JNES XXIV/4, 365-383

Van Siclen III, C.C. 1980: The temple of Meniset at Thebes, Serapis 6, 183-207

Weigall A.E.P.B. 1906: A report on the excavation of the Funeral Temple of Thoutmosis III at Gurneh, ASAE VII, 121-141

Wente, E.F., Van Sinclen III, C.C. 1976: A Chronology of the New Kingdom, [in:] Johnson, J., Wente, E.F. (Eds), Studies in Honor of George R. Hughes, SAOC 39, Chicago, 217-261

Winlock, H.E. 1917: A Restoration of the Reliefs from the Mortuary Temple of Amenhotep I, JEA IV, 11-15 


\section{ÉTUDES et TRAVAUX XXXI / 2018}

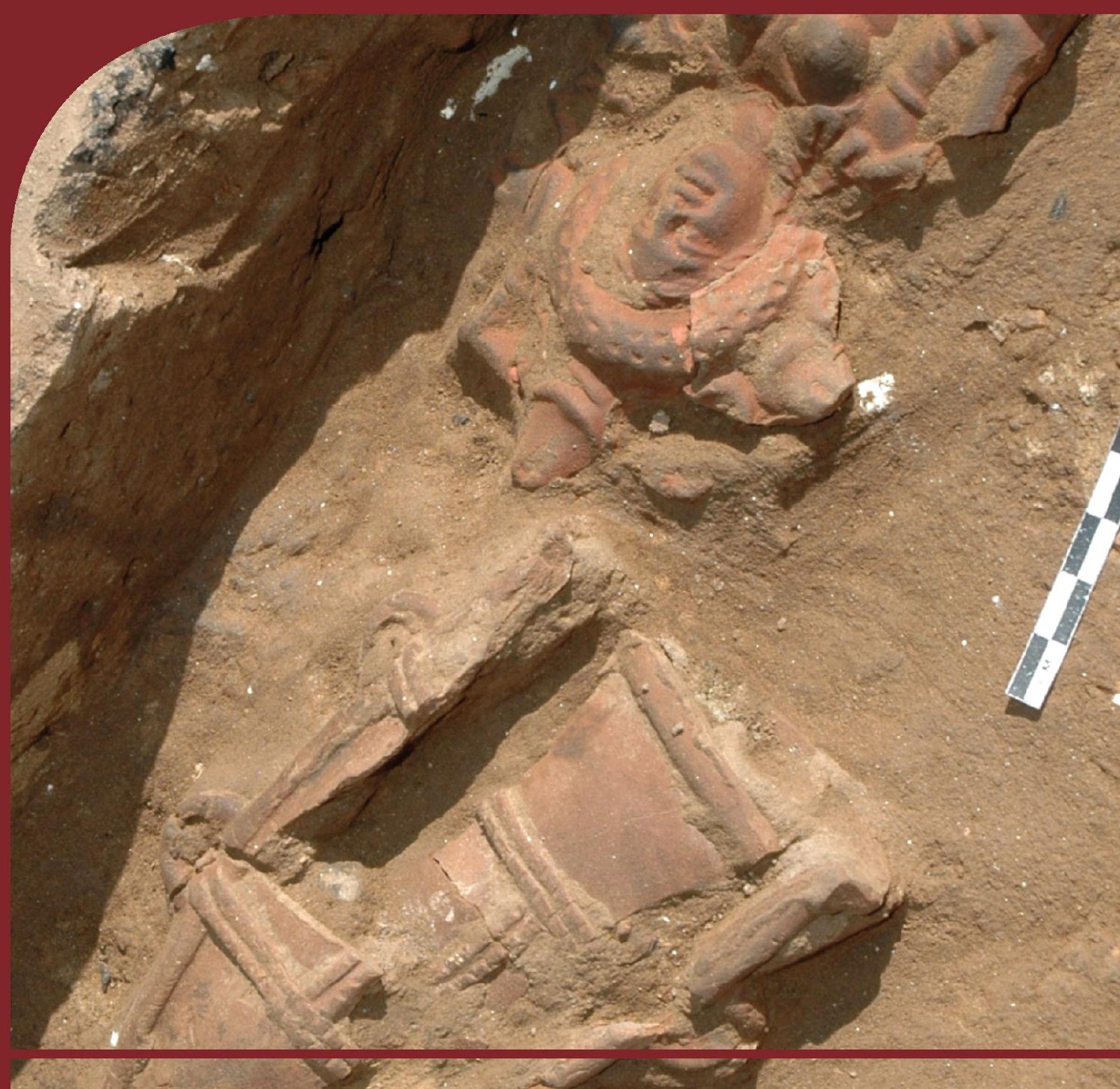

Institut des Cultures iyréditerranéennes et Oilentales FORIKSiO - de PAcadémie Polonaise des Sciences DS PA 


\section{COMITÉ DE RÉDACTION SCIENTIFIQUE}

Maciej Makowski - rédacteur en chef

Jadwiga Iwaszczuk - rédacteur

Mariusz Drzewiecki - sécretaire de la rédaction

Karol Myśliwiec - rédacteur thématique du volume

CONSEIL SCIENTIFIQUE DU JOURNAL

M. Kobusiewicz (IAE PAS, Warszawa), E. Laskowska-Kusztal (IMOC PAS, Warszawa)

D. Michaelides (University of Cyprus, Nicosia)

J.Ch. Moretti (IRAA-MOM, Université de Lyon 2/CNRS)

D. Raue (Ägyptisches Museum der Universität Leipzig), P. Reynolds (ICREA, España)

D. Welsby (British Museum, London)

\section{COMITÉ SCIENTIFIQUE DE LECTURE}

H.D. Baker (University of Toronto), P. Ballet (ArScAn-ESPRI, Université Paris Nanterre),

N. Beaux Grimal (IFAO, Cair/Collège de France, Paris), A. Dodson (University of Bristol),

L. Gabolde (CNRS), C. Gobeil (Egypt Exploration Society, London),

J. Holaubek (Institut für Ägyptologie, Wien), S. Ikram (American University in Cairo),

K. Innemée (Universiteit Leiden), Ch. Leitz (Universität Tübingen),

A. Loprieno-Gnirs (Universität Basel), Ch.E. Loeben (Museen für Kulturgeschichte, Hannover),

S. Ortisi (Universität München), A. Peignard-Giros (HiSoMA-MOM, Université de Lyon 2/CNRS),

E. Rova (Università Ca' Foscari Venezia), A. Sasson (San Diego Natural History Museum),

G. Schreiber (Eötvös Loránd University, Budapest), E. Teeter (University of Chicago),

Y. Tristant (Macquarie University, Sydney), V. Vaelske (independent researcher),

V.W.J. van Gerven Oei (independent researcher), H. Vymazalová (Charles University, Prague),

K. Winther-Jacobsen (Danish Institute at Athens),

J.A. Ostrowski, E. Papuci-Władyka, J. Śliwa (IA JU, Kraków),

R. Czerner (WUST, Wrocław), A. Ćwiek (IA AMU, Poznań),

K. Domżalski (IAE PAS, Warszawa), M. Pinker (FOS UW, Warszawa),

Ł. Niesiołowski-Spanò (IH UW, Warszawa), M. Gawlikowski (PCMA UW, Warszawa), K.O. Kuraszkiewicz (DE FOS UW, Warszawa), M. Barwik, P. Dyczek, W. Godlewski,

S. Rzepka, J. Żelazowski, A. Niwiński (IA UW, Warszawa)

\section{RÉDACTION TECHNIQUE}

Maciej Makowski, Jadwiga Iwaszczuk

CORRECTION LINGUISTIQUE

Jo Harper 
ÉTUDES et TRAVAUX

XXXI 
INSTYTUT KULTUR ŚRÓDZIEMNOMORSKICH I ORIENTALNYCH POLSKIEJ AKADEMII NAUK

\title{
STUDIA i PRACE
}

XXXI

\author{
gO IKŚiO \\ ESA PAN \\ WARSZAWA \\ 2018
}


INSTITUT DES CULTURES MÉDITERRANÉENNES ET ORIENTALES DE L'ACADÉMIE POLONAISE DES SCIENCES

\section{ÉTUDES et TRAVAUX}

XXXI

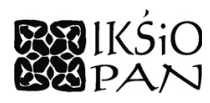

VARSOVIE

2018 
Publication scientifique financée dans le cadre du programme du Ministre de la Science et de l'Éducation Supérieure « Programme National de Développement de l'Humanistique » pour les années 2016-2021 (projet $n^{\circ} 3 \mathrm{bH} 15009983$ )

\title{
Harodowy PROGRAM ROZWOJU HUMANISTYKI
}

\author{
Copyright $($ ) \\ Instytut Kultur Śródziemnomorskich i Orientalnych PAN \\ et les Auteurs \\ Warszawa 2018
}

ISSN 2084-6762

(avant $2011: 0079-3566$ )

e-ISSN 2449-9579

Version première en papier, imprimée en Pologne - 150 copies

Version électronique accessible sur http://www.etudesettravaux.iksiopan.pl

Édition: Polskie Towarzystwo Historyczne et Wydawnictwo Neriton, Warszawa

Conception générale de couverture : J. Iwaszczuk Photo de couverture : P. Moser (C) Schweizerisches Institut für Ägyptische Bauforschung und Altertumskunde in Kairo

(terre cuites d'Aswan/Syene) 


\section{Table des matières}

KAROL MYŚLIWIEC

$(E T=E t u d T r a v / 50) \times 30$

HASSAN Aglan

Hatshepsut and the Apis Race: New Quartzite Relief Fragments

from Dra' Abu el-Naga

Amgad Joseph

Divine Wrath in Ancient Egypt

Amgad Joseph

Pain Infliction, Inflictors and Healers in Egyptian Religious, Magical

and Literary Perceptions

MirosŁaW BarwiK

New Dipinti in the Birth Portico of the Hatshepsut Temple at Deir el-Bahari

KrzyszTOF BorysŁaWsKi, ANNA NiwiŃSKA, ANDRZEJ NiwiŃSKI,

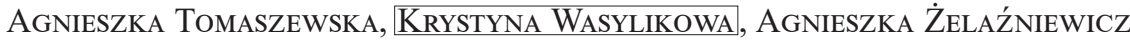

A Bulb of Narcissus on the Egyptian Mummy from University

of Wrocław Collection

LINDA CHAPON

Some Reliefs Representing the King in the Heb Sed Robe Discovered in the Henket-Ankh

Philippe Guillaume

Debunking the Latest Scenario on the Rise of the Pork Taboo

Mariola Hepa

A Clay Gladius Scabbard from Area 13c in the Ancient Roman Town of Syene

Emanuele E. Intagliata

Pinpointing Unrest at Palmyra in Early Islamic Period. The Evidence from Coin Hoards and Written Sources 
KATARZYNA KAPIEC

The Sacred Scents: Examining the Connection Between the ' $n t j w$ and $s f \underline{t}$ in the Context of the Early Eighteenth Dynasty Temples

DOMINIKA MAJCHRZAK

Remarks on the Iconographic Motif of the Birdman in Mesopotamian Glyptic Art of the Third Millennium BC

KAROLINA PAWLIK

Stone Artefacts from Late Roman Occupation Phases in Nea Paphos

ABRÉVIATIONS 
THE VOLUME IS PUBLISHED TO CELEBRATE

THE $50^{\text {TH }}$ ANNIVERSARY

OF THE

ÉTUDES ET TRAVAUX

ESTABLISHED IN 1966 